\title{
Space for self-expression: communication of Czech female athletes on social media and fans' reactions
}

\author{
Kateřina Turková*, Veronika Macková, Alice Němcová Tejkalová
}

\author{
Institute of Communication and Journalism Studies, Faculty of Social Sciences, Charles University, \\ Prague, Czech Republic \\ * Corresponding author: katerina.turkova@fsv.cuni.cz
}

\begin{abstract}
Social media platforms allow athletes to share information with the public. This opportunity is arguably more important for female athletes who traditionally receive less space in the mainstream media than their male counterparts. This article focuses on the social media self-presentation of six successful, internationally recognized, professional Czech female athletes and their fans' reactions. By using qualitative and quantitative content analyses, it was revealed that throughout the season, the selected athletes presented themselves as powerful professionals, while their off-season posting tended to be more personal and, for the most part, more feminine. Contrary to previous research, fans did not frequently respond with explicitly sexual or negative comments. Moreover, they supported and admired the athletes, and in most cases, reacted positively. A higher sensitivity was indicated in relation to the sportswomen's personal relationships and opinions. This leads us to the conclusion that social media enables professional female athletes to present themselves more freely than traditional media and be positively received by the public.
\end{abstract}

\section{KEYWORDS}

Facebook; sport; gender; presentation; content analysis

DOI

$10.14712 / 23366052.2021 .10$

\section{INTRODUCTION}

It has been noted that traditional media gives more coverage to male athletes (Jakubowska, 2015; Vann, 2014). Female athletes have appeared less often in the traditional media, and the portrayal has supported the stereotypical hegemonic masculinity view (Billings et al., 2018). Journalists have also paid less attention to the sport disciplines in which women dominate, as for example rhythmic gymnastics or synchronized swimming ( Jakubowska, 2015).

Currently, female athletes have the opportunity to "balance the force ratio" by using social media and share their content directly with their audience, without journalists

C 2021 The Authors. This is an open-access article distributed under the terms of the Creative Commons Attribution License (http://creativecommons.org/licenses/by/4.0), which permits unrestricted use, distribution, and reproduction in any medium, provided the original author and source are credited. 
transforming it into any kind of stereotyped coverage (Toffoletti \& Thorpe, 2018). Social media provides a platform for promoting athletic achievements and personal opinions and sharing the pieces of (private) everyday life that athletes themselves want to show to the public. This "exclusive" social media content is commonly sought and appreciated by fans, who often react positively to the athletes' posts (Bruce, 2016; Smith \& Sanderson, 2015).

Unfortunately, the online environment has not been flooded solely by positive responses, but also by extremely harsh and critical remarks from so-called fans, who have been termed "haters" - people who systematically rather than rationally criticize others, especially in the Internet environment (Dawson, 2018). The negative social media communication between athletes and their followers is often triggered by the possibility of direct interaction. Negative comments and reactions addressed to athletes through social media can adversely affect both the career growth and personal lives of the athletes targeted (Woodman \& Hardy, 2003). The availability of anonymous social media accounts demonstrably increases the level and intensity of hate speech (Dawson, 2018; Mondal et al., 2017). Moreover, the level of stress caused by micro-aggressive behavior or trolling by the public and fans in the social media environment can be even higher in the cases of female athletes (Woodman \& Hardy, 2003). Despite the aforementioned risks, social media communication represents a powerful and beneficial tool and should not be omitted by female athletes, as the results of this research show.

The study focuses on the communication of professional Czech female athletes on their official Facebook pages: track and field athlete Zuzana Hejnová, tennis players Petra Kvitová and Karolína Plíšková, skier and snowboarder Ester Ledecká, snowboarder Eva Samková and speed skater Martina Sáblíková. The ambition of this article is to analyze the communication strategies or approaches used by these six famous female athletes and the tone and manner of fans' reactions in the social media environment. Quantitative and qualitative content analysis methods were employed (Riffe et al., 2005; White \& Marsh, 2016), and all of the athletes' posts and fans' reactions from July 2018 to December 2019 were coded. This extensive period allowed us to cover both the in-season and off-season as well as providing sufficient analytic material for capturing possible trends in their communication. The primary aim of this article was to discover whether the processes and findings described in American and Western European athletes' social media analyses are applicable to athletes from Central Europe, since analyses from this region have been considerably neglected.

All the aforementioned sportswomen compete at the international level and have been globally successful in the long-term; hence their audiences consist of both Czech and English speakers. The athletes post in both languages, even though the combination of the languages varies depending on the individual personality. Naturally, the different audiences use various languages to express their opinions on the social media channels of the selected athletes. Because of this situation, we were also interested in learning if there was any difference between the Czech and foreign language comments.

\section{FEMALE ATHLETES AND SOCIAL MEDIA}

In a broad sense, social media are represented by various Web 2.0 forms, e.g., blogs, user-generated sites, online sites to share video and pictures, and podcasts. Fuchs 
(2017) noted that the later forms of social media which support: communication, collaboration, content sharing, and encourage building virtual communities, have greater impact and are nowadays used more frequently. Examples of these modern social media are, i.e., Facebook, Twitter, Instagram, and YouTube (Fuchs, 2017). Facebook is the most commonly used social media worldwide, as well as in the Czech environment (Statista.com, 2020). Among others, sports reporters also favor Facebook and Twitter in comparison with other social media channels as sources of information (Sheffer \& Schultz, 2015). Some of the most followed and liked profiles on Facebook are the accounts of popular athletes (Trackalytics.com, 2020). As athletes become celebrities, they step into the public sphere and literally share their lives with their admirers, giving fans a feeling of closeness (Weiss, 1996).

As previously mentioned, many authors have written about the fact that more coverage is given to male athletes in traditional media from the quantitative as well as the qualitative perspective (Fink, 2015; Jakubowska, 2015; Vann, 2014). Hardin (2005) remarked that sport was the domain of men in the past, and this stereotype persists. Female athletes gain press attention most commonly when they are visually attractive or significantly more successful than their male counterparts (Jakubowska, 2015). In this context, social media represents an opportunity for female athletes to present themselves in the ways they desire. Specifically, they can express their opinions and feelings to the wider public through these platforms without any kind of mediatization or outside influence. On the other hand, the social media environment remains a threat, especially concerning mental health. For example, the negative or rude fan reactions can stress the athletes and negatively affect the female athletes' performance. It has also been known to cause depression (BBC.com, 2020; Kubištová, 2020).

Existing research focusing on female athletes' self-presentation on social media has reported various results. For example, Emmons and Mocarski (2014) claimed that female athletes were more likely to pose for photos while male athletes are captured during a performance; hence the men are more often in motion and looking away from the camera. In contrast to this, Smith and Sanderson (2015) argued that female athletes nowadays present themselves more frequently as active women, posting photos taken during training or competition.

Differences have been discovered in the way female and male athletes use social media for promotional purposes (Voráček \& Čáslavová, 2019). Among others, Lebel and Danylchuk (2012) noted that female athletes could promote a wider range of brands and products than male athletes.

Overall, Hagay and Bernstein (2019a) provided a typology of female athletes' social media presence. Despite research concentrated specifically on Instagram, their findings are also applicable to other platforms, i.e., Facebook. The authors stated that the style of presentation could be influenced, for example, by age or an athlete's identity, and they distinguished three types of self-presentation by female athletes. "Professional athletes" mainly post photos of training and competitions, whereas "human athletes" provide fans not only with sports content but also insight into their personal lives. "Pro Instagram" athletes usually arise from the younger generation who use social media on a regular basis. Among others, they "participate and initiate joyful 'challenges', upload social photos and use emojis to accompany the photos," (Hagay \& Bernstein, 2019b, p. 71). 
Since the nature of social media helps to reduce physical barriers between athletes and their fans, and facilitates engagement between them, many passive media consumers have become content creators and and contributors, so-called produsers (Jenkins, 2006). Putting these changes into the context of the study, the visitors of athletes' social media pages can contribute to the content and create an important part of the publicly visible content on those pages. Overall, social media represents a powerful and useful tool, not only for athletes' self-promotion, but also for sharing their opinions and sponsors' promotion (Smith \& Sanderson, 2015; Toffoletti \& Thorpe, 2018). These new forms of media make it simple for athletes to strengthen relationships with their fans all around the world (Wann \& James, 2019).

Fans' responses to the published content are both positive and negative. Positive reactions from fans are often expressed through emojis. The visuality of the characters guarantees easier transfer of emotions than would be described by words (Danesi, 2017). Authors dealing with the topic of critical comments addressed to both male and female athletes revealed that their audience often criticized sports performance and results (Browning \& Sanderson, 2012; Franck \& Nüesch, 2012). In the case of female athletes, more critical voices were centered on physical appearance, such as an athlete's weight (Mutz \& Meier, 2016) or lack of femininity (Cooky \& Dworkin, 2013). Other problematic issues were sexual orientation (Hardin \& LaVoi, 2013) and an excessive amount of commercial content (Walsh et al., 2013). Discussions on lack of femininity were reported, for example, in the case of South-African runner Caster Semenya (Cooky \& Dworkin, 2013). Sanderson (2013) noted that hateful comments on social media could be caused by individual intentions or community movement, when the group of people jointly criticize similar things or behavior.

Moreover, female sports celebrities particularly deal with trolling, which can be described as an intentional impolite or aggressive behavior and manipulation, evoking conflict; hence the common purpose is to make fun of the actual person or provoke them (Lumsden \& Morgan, 2012, Ortiz, 2020). Although the gender of "trolls" could not be predicted, they often present, or even identify themselves, as men (Bishop, 2014; Lumsden \& Morgan, 2012). Additionally, Lumsden and Morgan (2012) highlighted that the victims of trolling are often women. Trolling as a form of bullying is also observable in computer-mediated communication and declared on celebrities' Facebook pages (Ortiz, 2020), and in more extreme instances, stalking was evidenced. Whereas trolling mostly focuses on a wide social group, stalking is more personally oriented. Cyberstalking includes ongoing visiting and observation of particular pages and can also be associated with repeated annoying comments published under the selected peoples' posts. Stalkers tend to read and react to each post (Antonini et al., 2019). Therefore, athletes must block the offending fans and followers.

\section{RESEARCH AIM}

The main objective of this research was to analyze the communication approaches used by six famous Czech female professional athletes and the tone and manner of fans' reactions in the social media environment. 


\section{METHODS}

To characterize female athletes' communication on social media, the official Facebook pages of six professional Czech female athletes (all of them competing in Olympic disciplines, three of them summer and three of them winter sports representatives) were chosen for analysis. Facebook as a platform was selected due to its popularity and wide use (Statista.com, 2020). The selected athletes have been successful and popular at the international level and their official Facebook pages have more than forty thousand fans and followers. The selected athletes represent two generations, Martina Sáblíková, Zuzana Hejnová and Petra Kvitová being in their thirties and Ester Ledecká, Eva Samková and Karolína Plíšková in their twenties. All of the selected athletes, except Track \& Field representative Zuzana Hejnová, are currently significantly more successful in their sports disciplines than their Czech male counterparts (cf. Zlatkovský \& Kočí, 2018).

Zuzana Hejnová is a track and field athlete who specializes in the $400 \mathrm{~m}$ hurdles. She has held the World Championship title in this discipline twice (in 2013 and 2015). In the same years, she also won the Diamond League. Additionally, she is a bronze medalist from the London 2012 Summer Olympics and a national record holder (Hejnova.cz, 2020). Petra Kvitová and Karolína Plíšková are tennis players and longtime members of the WTA Top 10. Kvitová has won Wimbledon two times, and in 2016 she won bronze at the Rio de Janeiro Olympics (Olympic.cz, 2018b). In December 2016, Kvitová was attacked by a man with a knife in her flat which resulted in her undergoing surgery on her left hand. However, she overcame these obstacles and returned to the top of the standings (Kvitová, 2020). Karolína Plísková has been a part of the WTA Top 10 since 2016. She was also the first Czech female tennis player to be ranked number 1 in the world by the WTA (Karolina-pliskova.com, 2020).

Ester Ledecká, Eva Samková and Martina Sáblíková are winter sports representatives. Ledecká is an alpine skier and snowboarder who became the first Olympian to win two gold medals in both alpine skiing and alpine snowboarding in PyeongChang in 2018 (Ledecká, 2020). Eva Samková is a snowboard cross rider who won the Sochi 2014 Olympic Games and placed third at the PyeongChang 2018 Winter Olympics in her discipline (Evasamkova.cz, 2014). Samková also achieved victory in the World Cup series in 2017 and 2019 and placed second at the X Games in snowboard cross two times (RedBull.com, 2020). Martina Sáblíková is a world speed skating celebrity; she specializes in long distance. She has attended four Olympic Games and won six Olympic medals, including three golds. Moreover, she is also a multiple World and European medalist and winner of World Cup standings (Nutrend.cz, 2020; Olympic.cz, 2018a).

The official Facebook pages of the selected female athletes in the observation period were managed both by themselves and by professionals. Eva Samková administered the Facebook page on her own; hence she had some social media training (Samková, WhatsApp communication, March 31, 2020). Zuzana Hejnová consulted with her manager Alexandr Kliment regarding social media content, especially in the case of promotional and commercial posts (Hejnová, personal communication, February 18, 2020). Petra Kvitová managed her social media profiles in collaboration with her spokesperson Karel Tejkal, and PR manager Katie Spellmann (Tejkal, personal communication, November 8, 2019). Karolína Plíškovás Facebook page was admin- 
istered by her manager and husband Michal Hrdlička (Hrdlička, personal communication, February 26, 2020). The social media content on Ester Ledecká's accounts were created and posted by Ledeckás team and monitored by SportInvest agency. The same agency helped Martina Sáblíková with social media postings (Pillár, personal communication, November 5, 2019).

Table 1 displays the athletes' names, sports disciplines and numbers of fans and followers of their official Facebook pages in the observation period. The data are also complemented by total numbers of likes, shares and comments of all posts published on the selected athletes' Facebook pages from June 2018 to December 2019.

Table 1 Selected Athletes' Names, Disciplines, FB Page Creation Dates and Data Derived from their Official Facebook Pages

\begin{tabular}{|c|c|c|c|c|c|c|}
\hline $\begin{array}{l}\text { Athlete's Name } \\
\text { and Discipline }\end{array}$ & $\begin{array}{l}\text { FB Page } \\
\text { Creation } \\
\text { Date }\end{array}$ & $\begin{array}{l}\text { N of Page } \\
\text { Likes }\end{array}$ & $\begin{array}{l}N \text { of Page } \\
\text { Followers }\end{array}$ & $\begin{array}{l}\text { N of Likes } \\
(06 / 2018- \\
12 / 2019)\end{array}$ & $\begin{array}{c}\text { N of Shares } \\
(06 / 2018- \\
12 / 2019)\end{array}$ & $\begin{array}{l}\text { N of Comments } \\
(06 / 2018-12 / 2019)\end{array}$ \\
\hline $\begin{array}{l}\text { Petra Kvitová } \\
\text { (Tennis) }\end{array}$ & July 20, 2011 & 652,470 & 643,833 & 463,975 & 8,276 & 23,111 \\
\hline $\begin{array}{l}\text { Martina } \\
\text { Sáblikková } \\
\text { (Speed Skating) }\end{array}$ & $\begin{array}{c}\text { February 9, } \\
2009\end{array}$ & 314,972 & 303,478 & 441,959 & 14,988 & 16,473 \\
\hline $\begin{array}{l}\text { Eva Samková } \\
\text { (Snowboarding) }\end{array}$ & $\begin{array}{c}\text { November 29, } \\
2011\end{array}$ & 189,246 & 187,851 & 129,115 & 1,426 & 2,021 \\
\hline $\begin{array}{l}\text { Ester Ledecká } \\
\text { (Alpine Skiing } \\
\text { \&Snowboarding) }\end{array}$ & $\begin{array}{c}\text { February 7, } \\
2012\end{array}$ & 155,740 & 166,476 & 439,039 & 8,028 & 10,222 \\
\hline $\begin{array}{l}\text { Karolína Plíšková } \\
\text { (Tennis) }\end{array}$ & April 15, 2015 & 116,634 & 119,084 & 329,973 & 4,802 & 12,362 \\
\hline $\begin{array}{l}\text { Zuzana Hejnová } \\
\text { (Track \& Field) }\end{array}$ & $\begin{array}{c}\text { March 22, } \\
2013\end{array}$ & 40,134 & 40,120 & 56,656 & 552 & 2,958 \\
\hline
\end{tabular}

The research was conducted using methods of quantitative and qualitative content analysis (Riffe et al., 2005; White \& Marsh, 2016), and all of the athletes' posts and fans' reactions for a period of one and half years, from July 2018 to December 2019, were coded. The qualitative content analysis played an essential part in the research, because the emphasis was placed both on the way various topics were presented by the sampled athletes and the type of fans' reactions. In total, we categorized the topic (sport or diversity) and other items of 988 posts and went through more than 67,000 comments under the content published by the athletes.

The following main research questions were formulated:

RQ1: How do the professional Czech female athletes present themselves on their official Facebook pages?

RQ2: What are the fan reactions to posts which are published on the official Facebook pages of the selected professional Czech female athletes?

At first, we focused on the topic of athletes' posts, deciding whether each post was sports-oriented or covered diverse areas. Sports posts referred to the sport in general, the sports discipline, or sports events and training routines, while diverse content 
covered other fields, e.g., free time activities, family and friends, pop culture or politics (Hambrick \& Mahoney, 2011; Guerin \& Clavio, 2015). The presence of interactive content, such as pictures, videos was also taken into account.

Secondly, we studied fans' reactions. We recorded the number of likes, comments and shares under each post (Ozanne et al., 2017). Another categorized item was the prevailing tone of comments under the post: a mostly positive, mostly negative, or neutral tone of the discussion. Positive comments included clearly positive reactions and supportive messages; neutral comments were not clearly negative or positive, unidentifiable or ambivalent reactions; and negative comments were defined as critical, offensive, rude or vulgar statements. The tone of the comments under the post were classified as mostly positive when the number of positive comments outnumbered the negative comments. The mostly negative posts were those where the critical reactions were more prevalent. If the ratio of positive and negative fans' reactions was equal, the tone of the comments was categorized as neutral. The quantitative content analysis categories used for this article are specified in Table 2.

Table 2 The quantitative content analysis categories

\begin{tabular}{l|l}
\hline \multirow{2}{*}{ Variable } & Values \\
\hline \multirow{2}{*}{ Seasonality } & Czech \\
\cline { 2 - 2 } & English \\
\cline { 2 - 2 } & Both/Without text/ Emoticons only \\
\cline { 2 - 2 } & Other \\
\hline \multirow{2}{*}{ Shares } & In the season \\
\cline { 2 - 2 } Comments & Off-season \\
\hline \multirow{2}{*}{ Type of comments } & N of shares of post \\
\hline \multirow{2}{*}{ Picture(s) } & N of likes of post \\
\hline \multirow{2}{*}{ Video(s) } & N of comments of post \\
\hline Topic of the post & Neutral comments \\
\cline { 2 - 2 } & Mostly positive comments \\
\cline { 2 - 2 } & Mostly negative comments \\
\hline & The post does not contain picture(s) \\
\cline { 2 - 2 } & The post contains picture(s) \\
\hline & The post does not contain video(s) \\
\cline { 2 - 2 } & The post contains video(s) \\
\cline { 2 - 2 } & Sport \\
\cline { 2 - 2 } & Diversity \\
\hline
\end{tabular}

The data were coded by three independent human coders. The data was processed manually because the need to assign meaning to the posts was essential (Burch et al., 2014). The reliability of the process (stability and reproducibility) was ensured. Reproducibility was checked; hence both percent agreement as well as Krippendorff's Alpha 
took values confirming the reliability and validity of the coding process (Lombard et al., 2002). Then, the coders also discussed the indefinite cases at project meetings, and the stability was reviewed (Riffe et al., 2005). For the coding and data processing online electronic forms (Google Xls Sheets) and MS Excel and SPSS Statistics programs were used (cf. Skalski et al., 2017).

The results of the qualitative content analysis allowed us to describe and compare the selected female athletes' social media presentation. For a deeper understanding and explanation of the athletes' posting, a qualitative approach was employed. As a result of the comprehensive and detailed qualitative content analysis, the authors were able to detect the similarities and differences in the selected female athletes' official Facebook content in the observation period. Analysis was conducted on both the textual and non-textual (e.g. visual, audiovisual and interactive) components of the communication of the selected female athletes on their official Facebook pages.

The qualitative approach also allowed the researchers to detect the positive and supportive statements, as well as negative and critical fans' statements, including trolling. Thus, all the comments were studied, and their manners and meanings were analyzed.

\section{RESULTS}

The results of the research were divided into two main subchapters: the athletes' postings and the fans' reactions. The section dedicated to the athletes' postings begins with describing the intensity of the selected athletes' Facebook communication. After that, their sports-related and diverse postings are presented and contextualized. The second part has a similar structure regarding the fans' reactions. First, the numbers and types of fans' and followers' reactions to selected athletes' communications in the observation period are summarized and compared. Secondly, consideration is given to the reactions to sports-related posts. Finally, the reactions to diverse posts are described and explained.

\section{Athletes' posting}

All of the sampled athletes covered sports and diverse topics on their official Facebook pages in the observation period; however the ratio of these categories differed. Sports-related posts prevailed on the pages of Petra Kvitová, Karolína Plíšková and Martina Sáblíková, whereas diverse posts appeared more often on Ester Ledecká's, Eva Samkovás and Zuzana Hejnová's official Facebook pages (Table 3). These results could be affected by the observation period; different lengths of season and off-season periods of the selected athlete's sports disciplines took place from July 2018 to December 2019.

\section{Sports-related posting}

Sport makes up a significant part of all of the selected athletes' lives, it is their job and fills their free time. Nevertheless, only three official Facebook pages of the sampled sportswomen were predominantly sports-oriented. The typical social media profile of a female athlete where sport dominates (Hagay \& Bernstein, 2019a) was that of the tennis player Petra Kvitová. The posts (displayed in Figure 1) show the athlete during the training process or at tournaments, and they are tightly connected to sports performance. 
Table 3 Total number of sports-related and diverse posts analyzed in the observation period

\begin{tabular}{l|c|c|c}
\hline Athlete's Name and Discpline & N of Analyzed Posts & N of Sports Posts & N of Diverse Posts \\
\hline Zuzana Hejnová (Track \& Field) & 127 & 59 & 68 \\
\hline Petra Kvitová (Tennis) & 171 & 91 & 80 \\
\hline $\begin{array}{l}\text { Ester Ledecká (Alpine Skiing \& } \\
\text { Snowboarding) }\end{array}$ & 230 & 85 & 145 \\
\hline Karolína Plíšková (Tennis) & 210 & 128 & 82 \\
\hline Eva Samková (Snowboarding) & 133 & 34 & 99 \\
\hline Martina Sáblíková (Speed Skating) & 127 & 81 & 46 \\
\hline Total N of Posts & 998 & 478 & 520 \\
\hline
\end{tabular}

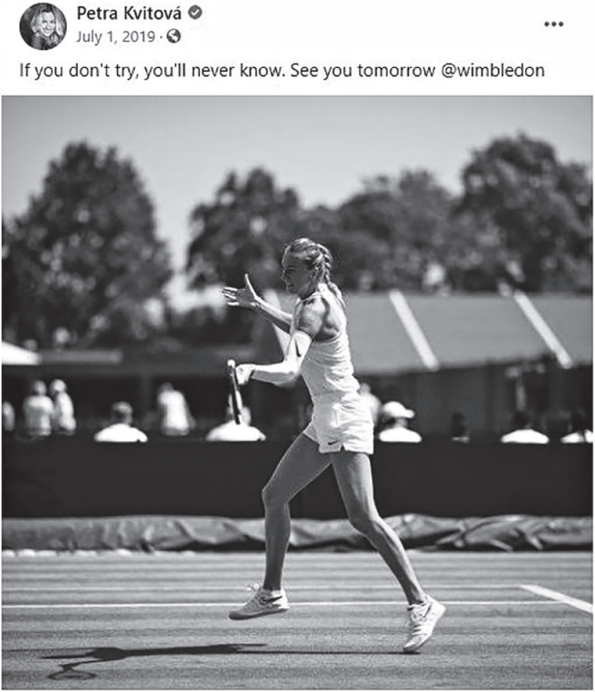

(1) $6.5 \mathrm{~K}$

344 Comments 76 Shares

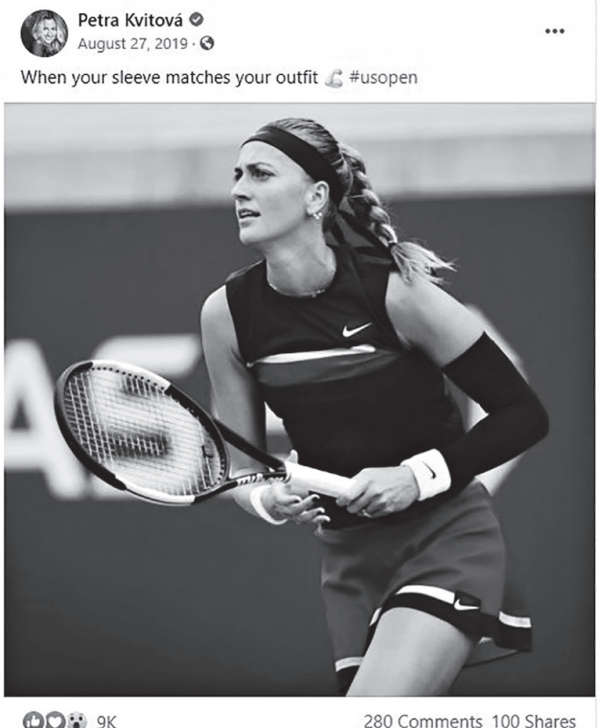

Figure 1 Two representative posts from the Facebook page of Petra Kvitová (July 1, 2019 and August 27, 2019).

Similar posts appeared on the Facebook pages of Karolína Plíšková and Martina Sáblíková, whose pages were also predominantly sports-oriented during the observation period. Among the aforementioned posts topics including training and competition, invitations to upcoming races and events could be found on athletes' Facebook Walls. For example, Martina Sáblíková announced the races where she had competed and let her own fans know on which TV channel the race had been broadcast (Figure 2).

Sports-related posts were also used for commercial purposes, as some of the sampled female athletes were involved in social media paid partnerships. Karolína Plíšková connected this type of partnership with sports-related content, as displayed in Figure 3. All other athletes in our sample presented advertisements directly with the given products or through photos from everyday life. 


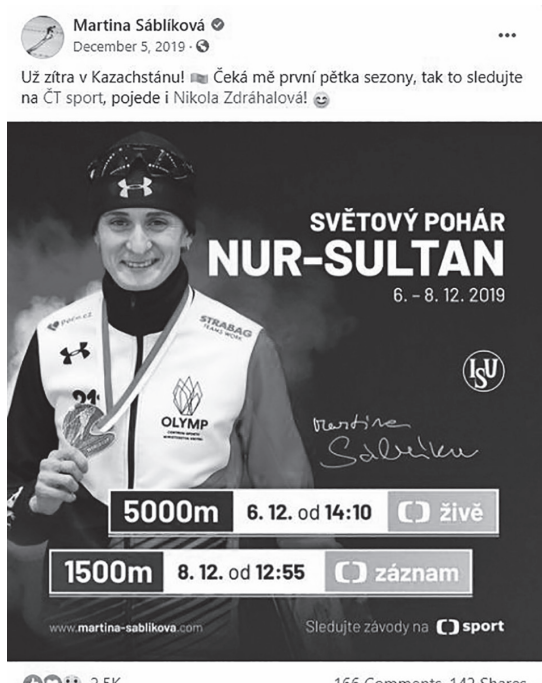

Figure 2 The example of a competition announcement from the Facebook page of Martina Sáblíková (December 5, 2019). Translation of the post: Tomorrow in Kazakhstan! Kz The first $5 \mathrm{~km}$ race of the season awaits me, so watch it on ČT sport, Nikola Zdráhalová will also compete! (-)

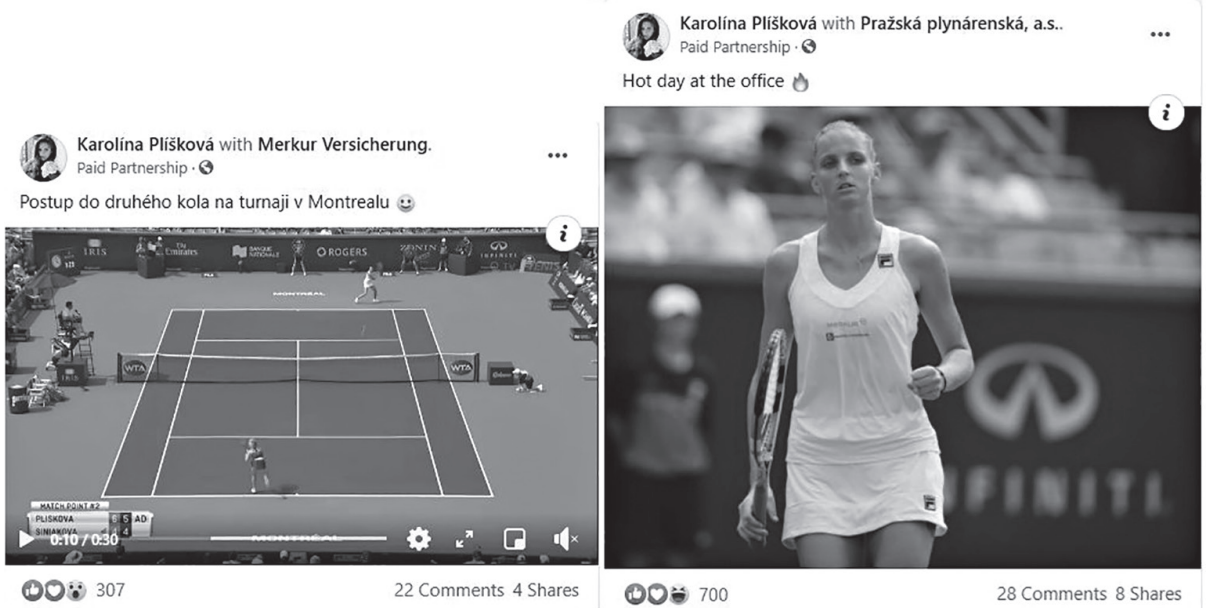

Figure 3 Examples of paid partnership connected with sports content on Karolína Plískovás Facebook page (August 7, 2018). Translation of the post on the left: Advance to the second round of the tournament in Montreal (-)

While talking about sports-related videos on selected athletes' Facebook pages, the videos were shot by the media or sponsors and then the athletes posted them. The official Facebook page was also a space for self-promotion and sharing of articles and reports about successes at competitions.

\section{Diverse posting}

Throughout the observation period, all of the sampled athletes published significant numbers of posts to their official Facebook pages which were classified into the diverse 


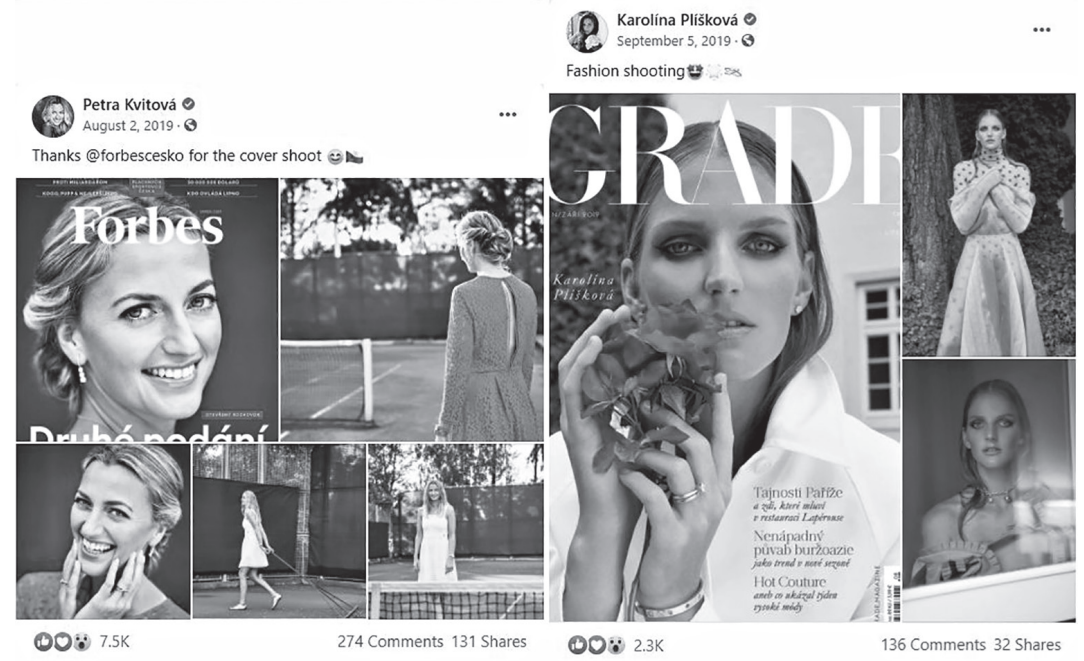

Figure 4 Posts from the Facebook pages of Petra Kvitová (August 2, 2019) and Karolína Plísková (September 5, 2019).
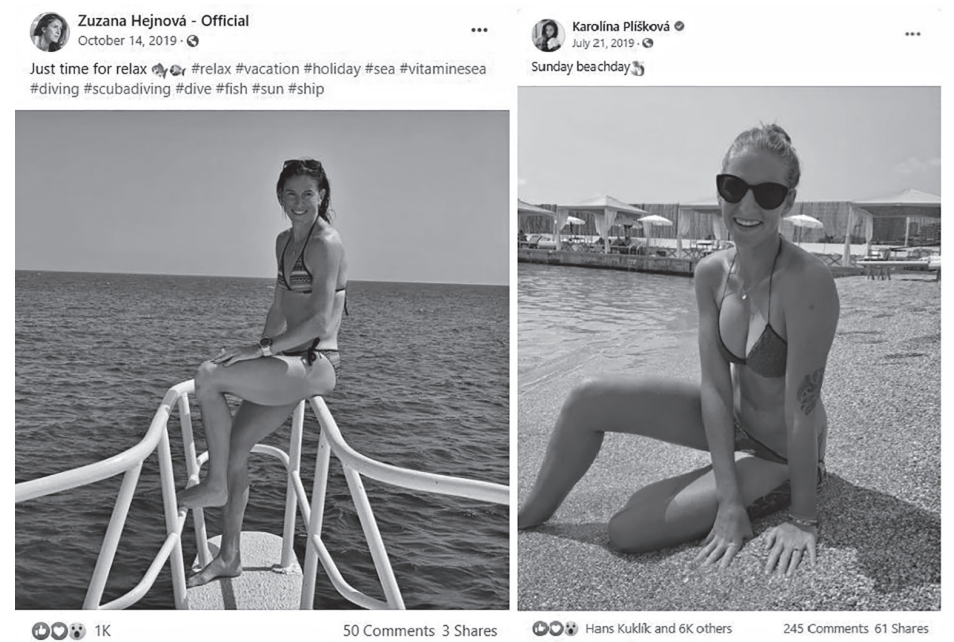

Figure 5 Example of a post from the diverse category of posts from the Facebook pages of Zuzana Hejnová $(0$ ctober 14, 2019) and Karolína Plíšková (July 21, 2019).

category. When sportswomen added posts with photos from their private life, they tried to look more feminine than on directly sports-related pictures. On the other hand, the published photos had no sexual undertone, as confirmed by posts of Petra Kvitová or Karolína Plíšková (Figure 4).

As Kong and Harris (2015) argue, the sportswomen's bodies often meet the ideal of kalokagathia. Therefore, many athletes like to show the positive effect participating in sport has had on their bodies and pose in swimsuits. These pictures were also present in the posts of the athletes we sampled, whether it was spending a holiday in a swimsuit (Figure 5) or a challenge in the form of winter hardening in cold water. 
The clearest example of an athlete whose posts were not predominantly oriented towards sports competitions and results was snowboarder and skier Ester Ledecká. She shared glimpses of ordinary life on her Wall and exemplifies the new generation of female athletes' approach to social media, her communication being more inventive. Ledecká has been very popular, and she likes to make jokes about herself and other people as evident in Figure 6 which shows how Ledecká created a funny contrast using two consecutive posts.

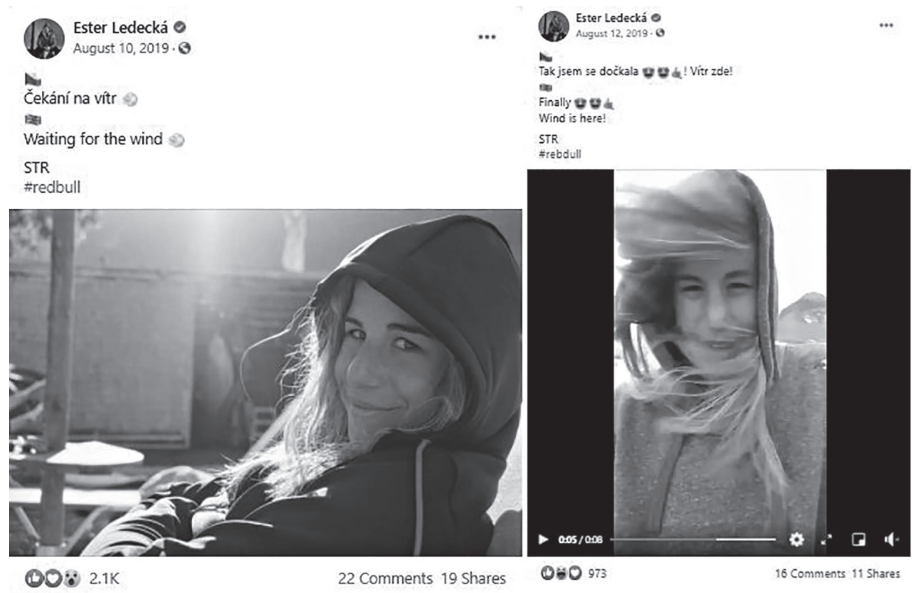

Figure 6 Posts from the Facebook page of Ester Ledecká (August 10, 2019 and August 12, 2019).

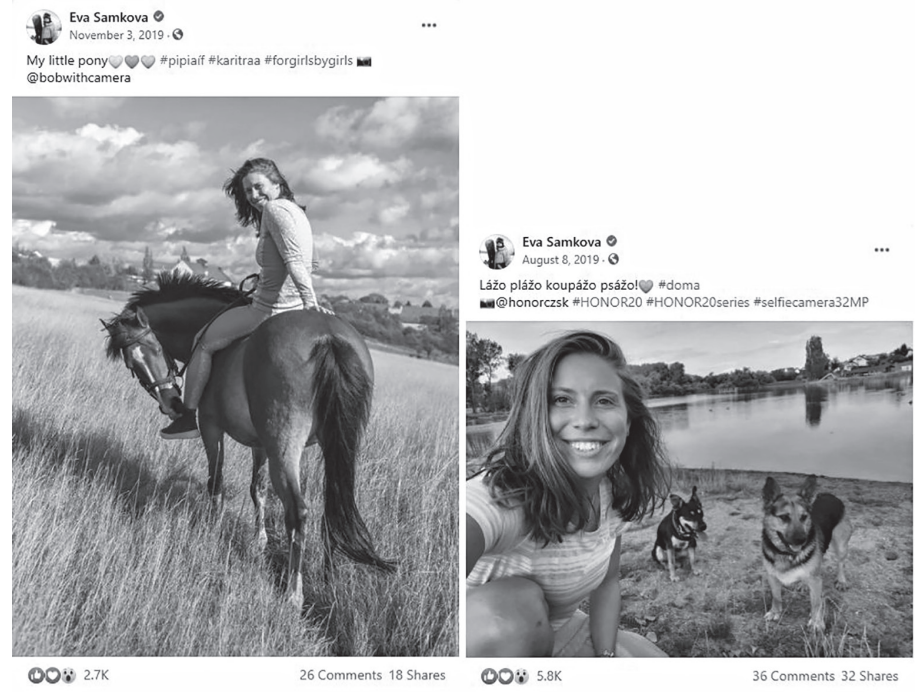

Figure 7 Typical posts with a diversity of content from the Facebook pages of Eva Samková (November 3, 2019 and August 8, 2019).

Translation of the post on the right: Relax, swimming and dogs!㸷 \#doma @ @honorczsk \#HONOR20 \#HONOR20series \#selfiecamera32MP 


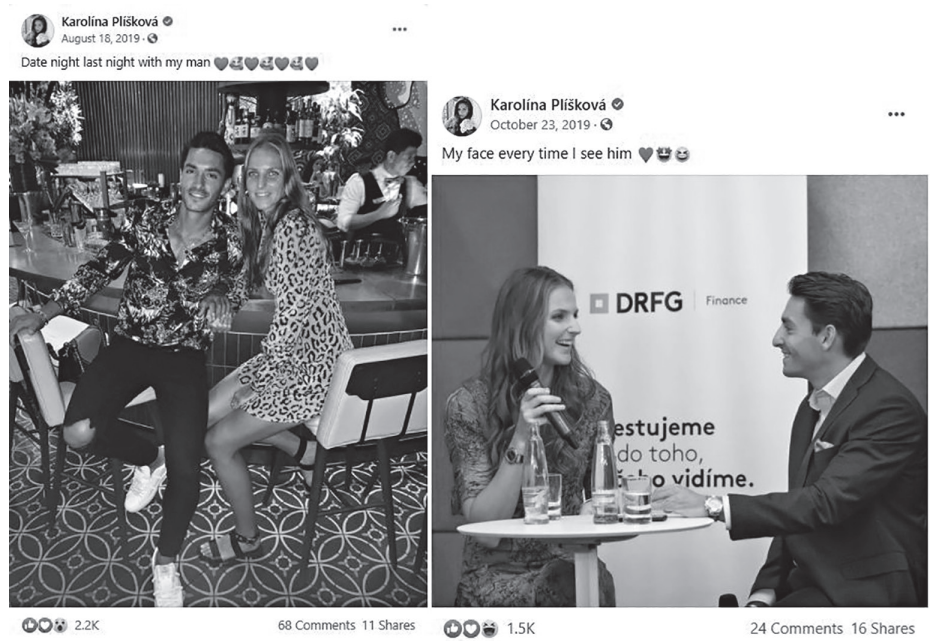

Figure 8 Karolína Plǐšková and her husband Michal Hrdlička on Plišková's Facebook page (August 18, 2019 and 0ctober 23, 2019).

Czech skier and snowboarder is the Facebook version of Hagay's and Bernstein's (2019) "pro Instagram" athlete. Since, on social media, private content is frequently valued more than information about the followed person's professional life (Ozanne et al., 2017), Ledecká's most liked post (13,373 likes and 566 comments) was not about sport, but rather a post about the successful completion of her BA studies. Like Ester Ledecká, Eva Samková gave fans a glimpse into her private life. The Czech snowboarder showed her interests, how she spent her free time and has been well regarded for her relaxed lifestyle and presentation (Figure 7).

Karolína Plísková is the only one of our sample of sportswomen who showed a partner on her Facebook page. The former presenter of sports news is not only her husband but also her manager, and he has attended tournaments with Plišková all over the world. He often appeared in the pictures published on her page, usually sharing a private moment with his wife (Figure 8).

Commercial or self-promotional content ${ }^{1}$ was present in all of the posts categorized as diverse in the analyzed athletes' posts. Although Ledecká and Samková posted a lot of diversity and commercial content, promoting namely lifestyle clothes, cell phones and cars, the posts were not always correctly disclosed as advertisements or endorsements by the aforementioned athletes.

Competitions were another form of promotion commonly organized on the athletes' pages, such as STARLIFE or Le Gracie competition presented by Zuzana Hejnová (see Figure 9). They give the fans a chance to win products from the company who is sponsoring the athlete. Furthermore, these forms of promotion usually produce high numbers of fans' interactions. In the case of Zuzana Hejnová, this kind of post received on average three times more reactions and comments than other types of postings.

1 For this purpose, all the posts endorsing or supporting the sporting event, corporate sponsor, product, activity, or mentioning the sponsors were categorized as commercial ones. 

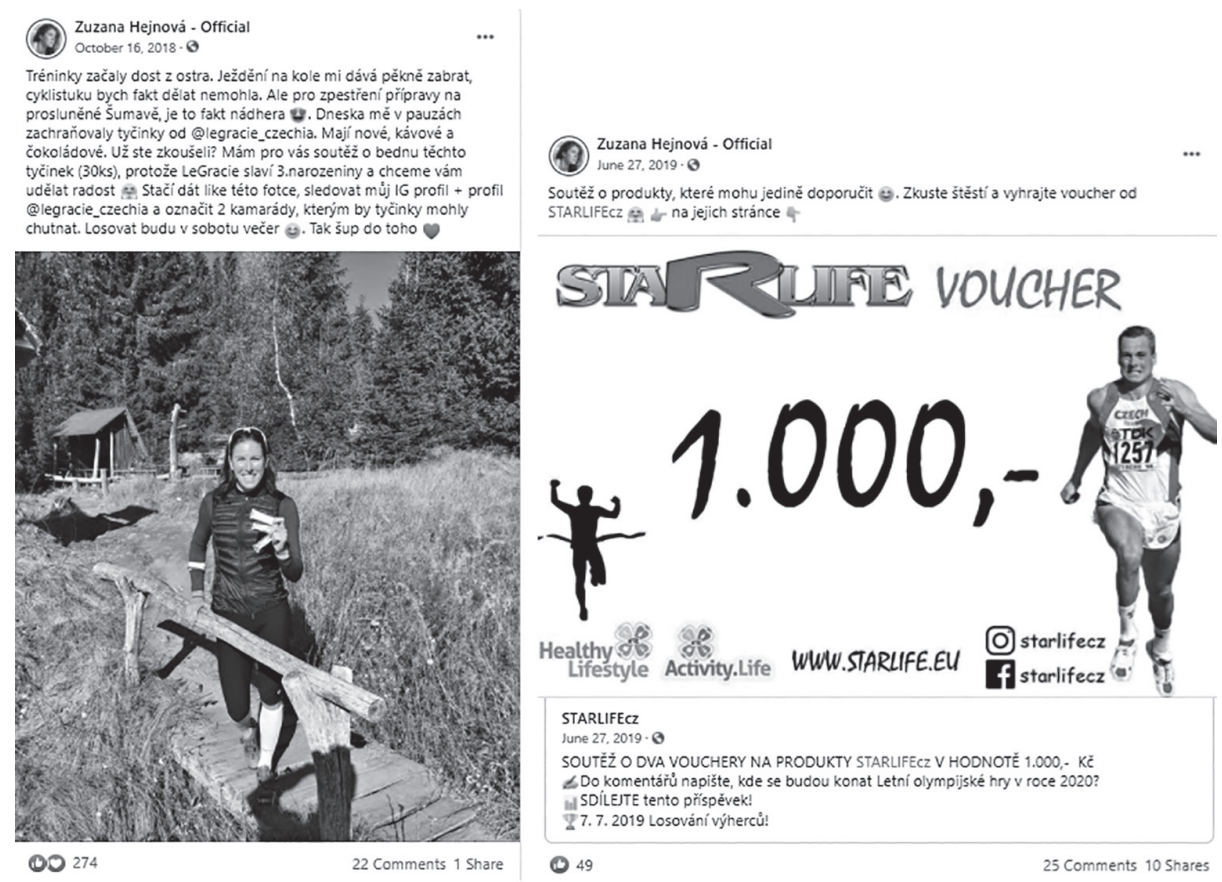

Figure 9 Products and Companies Promoted by Competitions on Official Facebook Page of Zuzana Hejnová (October 16, 2018 and June 27, 2019).

Translation of the post on the left: The training started pretty hard. Riding a bike destroys me, I really couldn't do cycling. But as part of the preparation for the sunny Šumava, it's really beautiful $-\odot$. Today, I was saved by bars from @ legracie_czechia. They have new flavors: coffee and chocolate. Have you tried it yet? I announce a competition for a box of these bars (30pcs), because LeGracie is celebrating its 3rd birthday and we want to make you happy (-) Just like this photo, follow my IG profile + @legracie_czechia profile and tag 2 friends who might like the bars. I will draw on Saturday evening (-). So go ahead

Translation of the post on the right: Competition for products I can truly recommend (-). Try your luck and win a voucher from STARLIFECZ $(-)$ ( 3 on their page $m$

\section{Fans' reactions}

The sampled female athletes' social media presentations and postings evoked different forms and intensity of fans' and followers' responses. Tennis player Petra Kvitová received the highest number of page likes and followers as well as total number of likes and comments under the posts in the observation period. The most shares of content were recorded on the Facebook page of speedskater Martina Sáblíková, which was the second most liked official page from the sample. The lowest number of page likes and followers, and also the lowest number of likes and shares under the posts belonged to Track \& Field athlete Zuzana Hejnová, which may have been due to the Hejnová's unsuccessful 2018 season, when she had to deal with an injury (ČTK, 2018; Macek \& Tomíček, 2018). Although her results improved significantly in 2019, she did not achieve the similar successes as e.g. in 2012, 2013 or 2015 (Hejnova.cz, 2020).

The correlation matrix (Table 4) shows that the topic of the post did not significantly influence the prevailing tone of comments under the posts. On the other hand, 
the sports-related postings were accepted mostly positively, whereas the discussions under diverse content published e.g. by Eva Samková, Karolína Plíšková or Martina Sáblíková had more neutral or negative prevailing tenor than their sport posts.

Table 4 Prevailing tone of comments under sports- and diverse-related posts on selected athletes' official Facebook pages analyzed in the observation period (correlation matrix)

\begin{tabular}{|c|c|c|c|c|c|c|c|c|c|}
\hline \multirow{2}{*}{$\begin{array}{l}\text { Athlete's Name } \\
\text { and Discpline }\end{array}$} & \multirow{2}{*}{$\begin{array}{c}\mathrm{N} \text { of } \\
\text { Analyzed } \\
\text { Posts }\end{array}$} & \multirow{2}{*}{$\begin{array}{l}\mathrm{N} \text { of } \\
\text { Sports } \\
\text { Posts }\end{array}$} & \multicolumn{3}{|c|}{$\begin{array}{l}\text { N of Post with Prevailing } \\
\text { Tone of Comments }\end{array}$} & \multirow{2}{*}{$\begin{array}{c}\mathrm{N} \text { of } \\
\text { Diverse } \\
\text { Posts }\end{array}$} & \multicolumn{3}{|c|}{$\begin{array}{l}\text { N of Post with Prevailing } \\
\text { Tone of Comments }\end{array}$} \\
\hline & & & + & 0 & - & & + & 0 & - \\
\hline $\begin{array}{l}\text { Zuzana Hejnová } \\
\text { (Track \& Field) }\end{array}$ & 127 & 59 & 58 & 1 & 0 & 68 & 63 & 4 & 1 \\
\hline Petra Kvitová (Tennis) & 171 & 91 & 91 & 0 & 0 & 80 & 80 & 0 & 0 \\
\hline $\begin{array}{l}\text { Ester Ledecká (Alpine } \\
\text { Skiing \& Snowboarding) }\end{array}$ & 230 & 85 & 81 & 3 & 1 & 145 & 137 & 7 & 1 \\
\hline Karolína Plišková (Tennis) & 210 & 128 & 106 & 17 & 5 & 82 & 67 & 13 & 2 \\
\hline $\begin{array}{l}\text { Eva Samková } \\
\text { (Snowboarding) }\end{array}$ & 133 & 34 & 33 & 1 & 0 & 99 & 87 & 12 & 0 \\
\hline $\begin{array}{l}\text { Martina Sáblíková } \\
\text { (Speed Skating) }\end{array}$ & 127 & 81 & 79 & 2 & 0 & 46 & 41 & 5 & 0 \\
\hline Total N of Posts & 998 & 478 & 448 & 24 & 6 & 520 & 475 & 41 & 4 \\
\hline
\end{tabular}

Overall, our analysis proved that the prevailing tone of comments under the posts published by the sampled athletes in the observation period was positive (Table 4; Figure 10). Only ten contributions in the whole sample received predominantly negative comments (i.e. more than $50 \%$ of comments to them were negative). Seven of the posts which received negative comments were published by Karolína Plíšková (Figure 10).

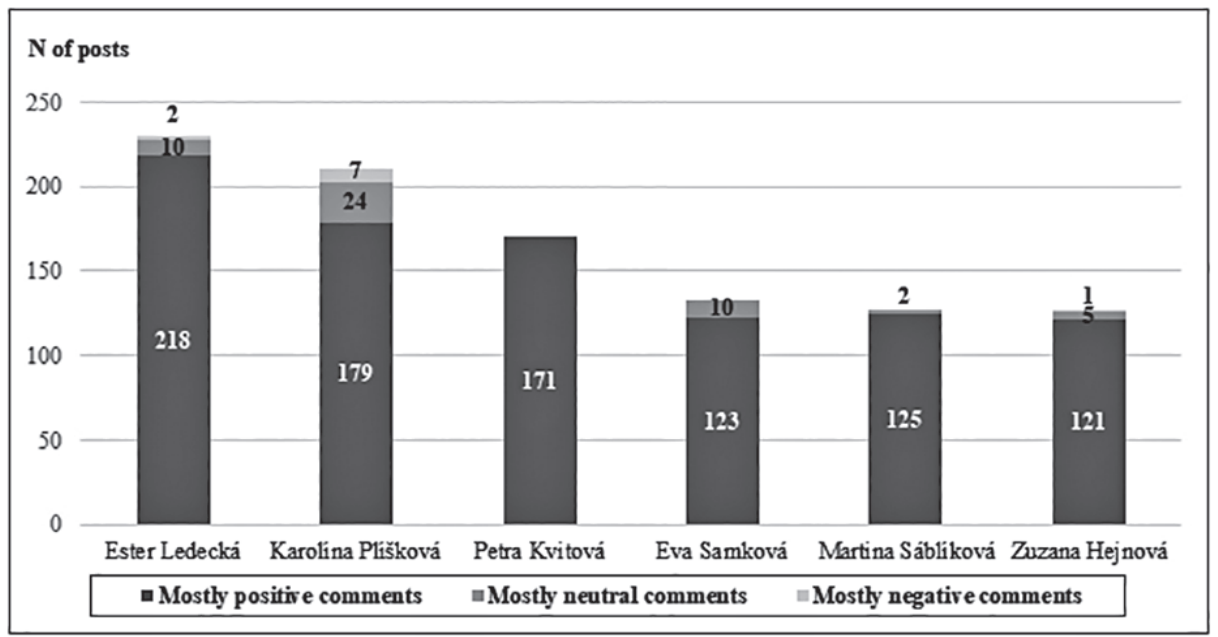

Figure 10 Prevailing tone of comments on all selected Facebook pages. 
The number of posts with a neutral tone (i.e. more than $50 \%$ of reactions were neutral) was higher (51 posts), but in total numbers it was still a small minority. On the other hand, between Martina Sáblíková, Eva Samková and Petra Kvitová we did not record a single mostly negatively commented on post on any of their pages. Moreover, all of Petra Kvitová's contributions in the observation period were evaluated positively (Figure 10).

\section{Reactions to sports-related posts}

The sports-related postings of the sampled athletes were predominantly positively received. Similarly, the posts aimed at athletes' sports performance, usually complemented by visual or interactive elements, belonged to the group of the most liked, commented and shared posts. For example, the most commented post published on Karolína Plíšková's Facebook Wall during the observation period was published after her victory at the Australian Open in 2019 where she defeated Serena Williams and advanced to the semifinals (Figure 11). This was an example of a post based on sports photography, and the reactions to it were mostly positive.

Another type of positively accepted sports-related posts were announcements of individual and team achievements and successes. Figure 12 displays the posts on Sáblíkovás Facebook page which received the highest number of shares and comments during the observation period. The most shared post was Sáblíkovás announcement of breaking the $3000 \mathrm{~m}$ world record. The second one contained a summary of the season and an acknowledgement to her team and fans which received more than 33,000 likes.

On the other hand, critical and abusive comments were also identified under the selected athletes' sports posts, however, most of those were aimed directly at their performance or results. One rare example of an aggressively commented sports-related contribution posted on Samkovás page referred to a podium picture (Figure 13) early in the season, accompanied by the reactions of one man shaming Eva Samková's weight without any provocation ("Small and fat", "it could be better, you are not moving and you have gained weight, haven't you?”). These comments were immedi-

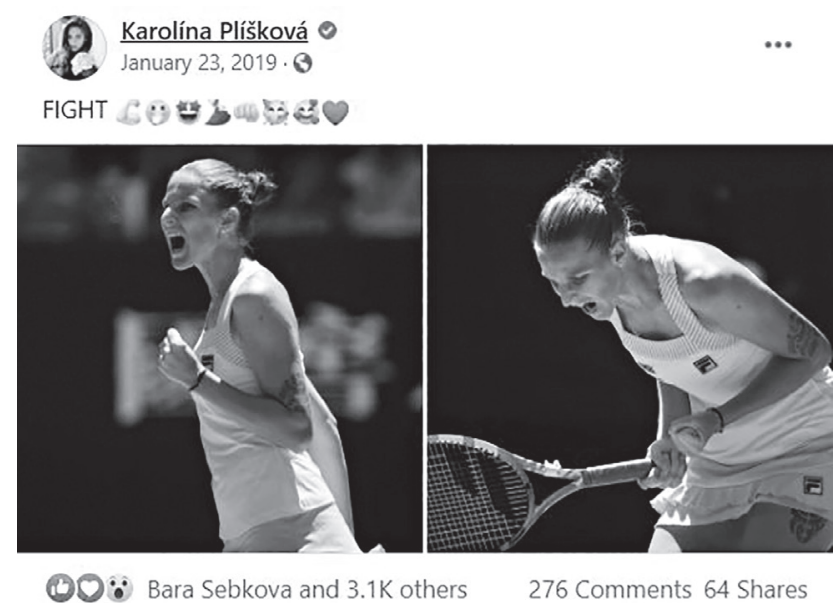

Figure 11 The most commented on post from the Facebook page of Karolína Plišková (January 23, 2019). 

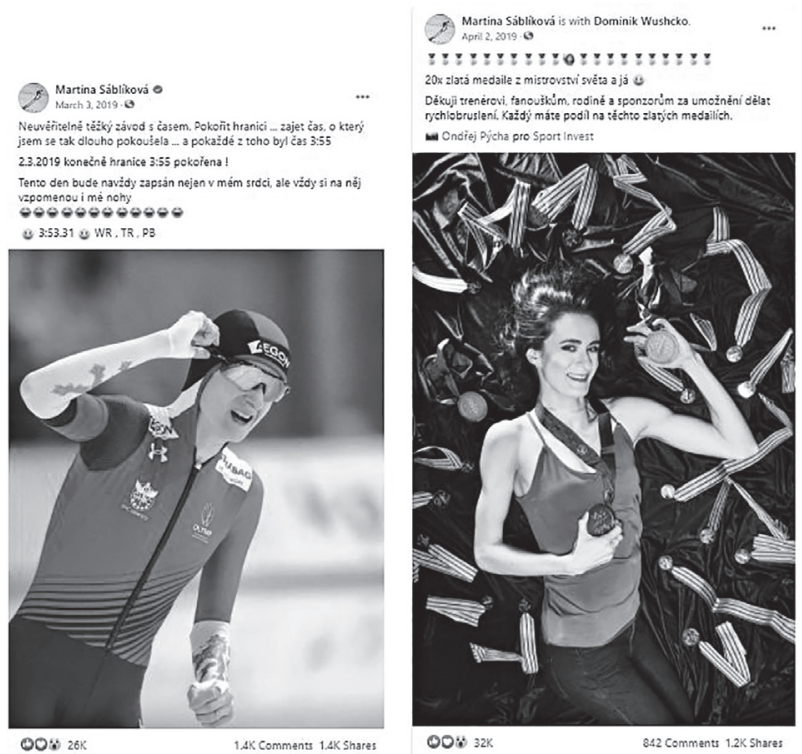

Figure 12 The most shared and commented posts from the Facebook page of Martina Sáblíková (March 3, 2019, and April 2, 2019).

Translation of the post on the left: An incredibly difficult race against time. Break the border ... take the time I've been trying for so long ... and the time was always 3:55. March 2, 2019, the 3:55 border is finally broken! This day will forever be written not only in my heart, but my feet will always remember it. (2), -), Translation of the post on the right: (1) (1) (1) (1) (1) (1) (1) (1) (1) World Cup and I (:) Thanks to the coach, fans, family and sponsors for allowing me to do speed skating. Each of them have a share in these gold medals. 0 Ondřej Pýcha for Sport Invest
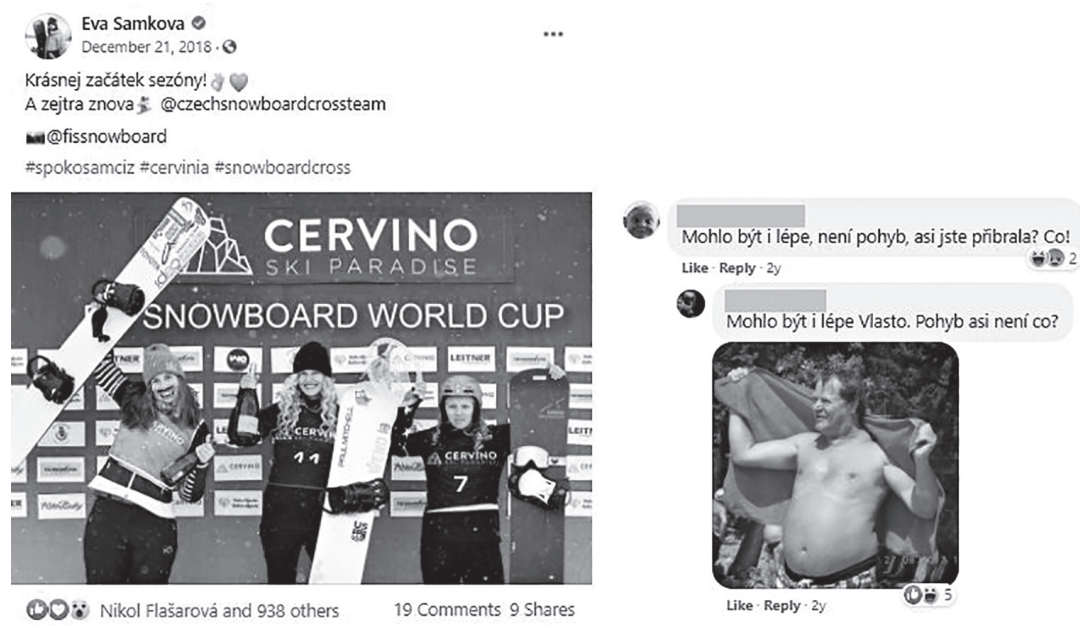

Figure 13 A post with a comment shaming Samkovás body and another fan's reaction to it from the Facebook page of Eva Samková (December 21, 2018).

Translation of the post: Beautiful start of the season! And tomorrow again @czechsnowboardcrossteam 으 @ fissnowboard \#spokosamciz \#cervinia \#snowboardcross 


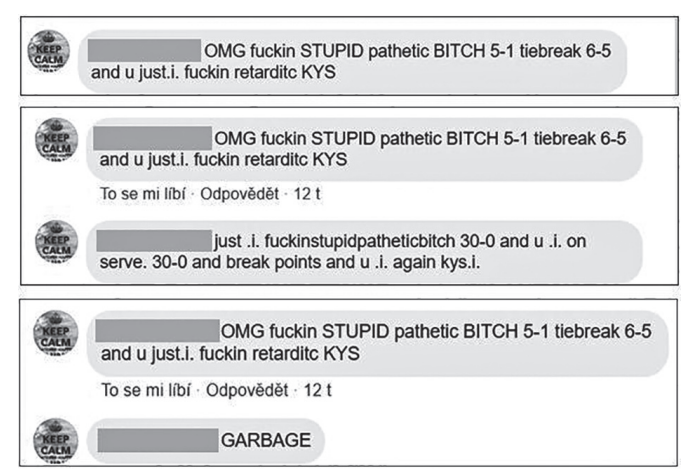

Figure 14 Examples of trolling on the Facebook page of Karolína Plí̌ková (September 28, 2018; 0ctober 3, 2018; 0ctober 10, 2018).

ately rebuked by several of Samkovás fans. In particular, one of Samkovás supporters posted one of the provocateur's own profile pictures, in which he is shown to be unathletic and out of shape, with the ironic caption of "It could be better, Vlasta. You are not moving, are you?".

Besides the aforementioned negative reactions, instances of trolling were discovered on the selected tennis players' official Facebook pages during the observation period in connection to sports-related content. One of the examples, three screenshots of the comments from the same person who commented on Karolína Plíškovás sports-related posts is shown in Figure 14. Negative reactions to the match and the result were disproportionate to the situation.

This person's comment had appeared several times under a few different posts, but it was not the only example of trolling on the tennis players' pages. Negative reactions under Petra Kvitovás content used vulgar and disgusting language similar to reactions on Karolína Pliškovás Facebook page. In some cases the tennis player was even accused of throwing matches. These "trolls" reacted to Kvitová's posts.

Tennis PR manager Karel Tejkal claimed in an interview that this behavior was typical for unsuccessful bettors and was already legally prosecuted in the Czech Republic. "It's even more specific to those tennis players that bettors often do it. Then, in frustration, when tickets are torn, they go and write a lot," (Tejkal, personal communication, November 8, 2019).

\section{Reactions to diverse posts}

The majority of reactions to diverse postings were positive as well. Among the written statements, visitors of the athletes pages sampled for this research used emojis to express positive or negative reactions. In our research, positive emojis predominated (the same results were observed by Danesi (2017). The positive emojis usually appeared under the postings with mostly positive reactions, which amounted to 923 of 998 posts in total.

With the exception of clearly positive reactions, sports celebrities also have to deal with the fact that people think they know them very well and live their lives with them (Weiss, 1996). These unsolicited reactions appeared more often under the diverse-oriented postings. Typical examples were the comments of Sáblíková’s Czech fan who 
described there his whole day, including a precise summary of his daily activities and routines (e.g. information about testing a new computer keyboard, description of the first day in a new job, etc.). Despite the fact that Martina Sáblíková never wrote him back, he continued to post in a similar way.

The pieces of everyday lives of the sampled athletes were accepted both positively and negatively, depending on the athletes' reputation or media coverage. As visible from Eva Samkovás most popular post from the analyzed period (Figure 15), the

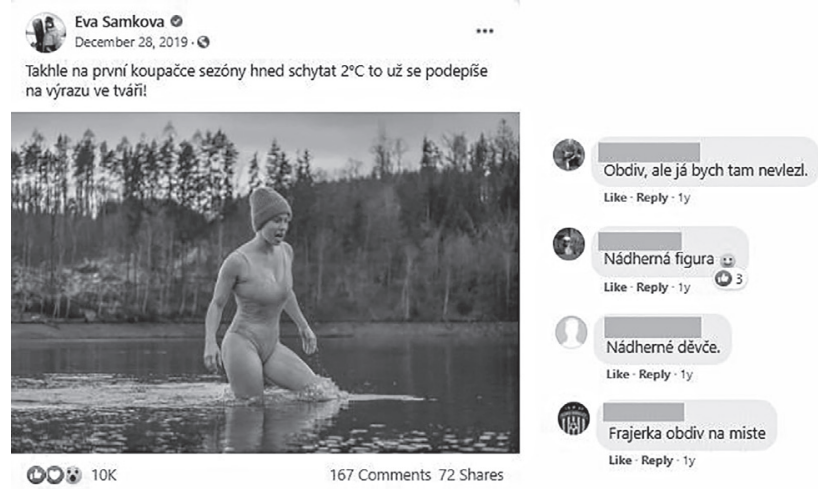

Figure 15 The most liked post (and typical comments) from the Facebook page of Eva Samková (December 28, 2019). Translation of the post: This is how it looks when the temperature is $2^{\circ} \mathrm{C}$ on the first swimming of the season. It has to be reflected in my face expression!

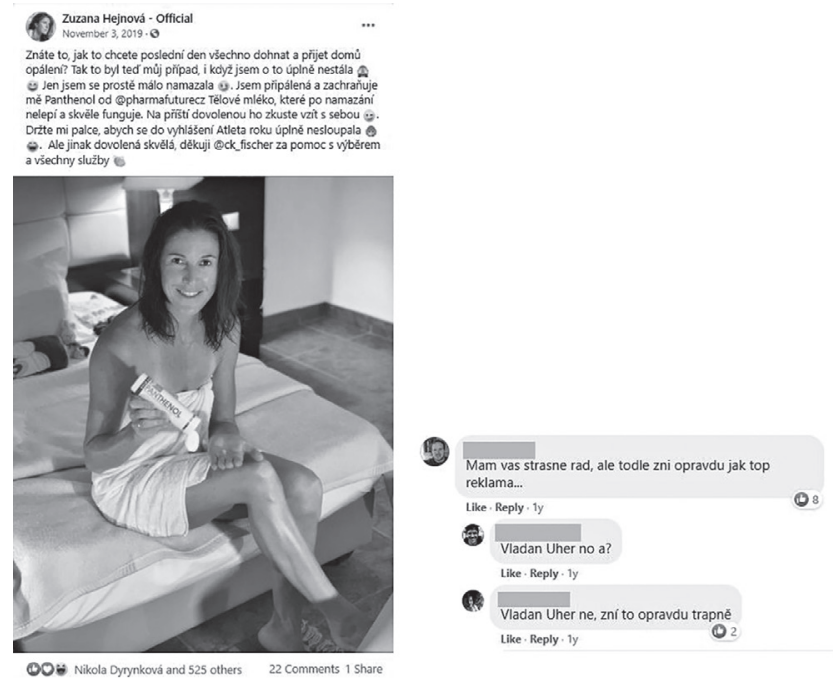

Figure 16 A partially negatively commented on post from the Facebook page of Zuzana Hejnová - Official (November 3, 2019).

Translation of the post: Do you know how you want to catch up on the last day and come home tan? So that was my case now, even though I didn't care at all 20 (-) I just smeared a little (-). I'm burned and saved by Panthenol from @ pharmafuturecz Body lotion that doesn't stick after lubrication and works great. Try taking it with you on your next vacation $\odot-$. Keep your fingers crossed that I won't be completely peeled off until the Athlete of the Year is announced \&\&. 8 . But otherwise a great holiday, thank you @ck_fischer for help with the selection and all services viuiu 
diverse posting was commonly accompanied by appreciative comments like "admiration, I would not dare to give it a try," "a beautiful girl," "a beautiful body" or "dude, the admiration is appropriate" (gaining 10,373 likes and 167 comments). These reactions contrast with the rare nonacceptance of Samkovás sports-related post, as seen in Figure 12, where she wore winter clothes, and the fan shamed her body.

Regarding the differences in the tone of comments, based on the language of the reaction, no generalizing variation was found between those written in the Czech and English language on the prevalently negatively commented posts. In the case of Ester Ledecká and Zuzana Hejnová, the negatively commented on posts were in Czech and the reactions were also in the Czech language.

In very few cases, mainly Czech-speaking fans had a problem with the promotional aspects of the post (either with a paid partnership or only a photo with a certain product). One of the negatively received posts released by an athlete in the sample was Hejnová's half-commercial for after-sun lotion and a travel agency (Figure 16), with comments of this kind: "I like you very much but this sounds really like a top commercial," or "It sounds really embarrassing," but still, the majority of reactions to this content were positive. Hejnová wrote in the post that she had sunburnt her skin while on vacation and the after-sun lotion of one particular brand saved her; thus, she recommended fans take it with them on holidays. Then she thanked the travel agency for help with her stay. What puzzled people the most was the absence of a clear statement if it was or was not a paid partnership (Hejnová defended herself in the following discussion below the post that the published content presented her partnership with the after-sun lotion producer, but she had no kind of agreement with the travel agency).

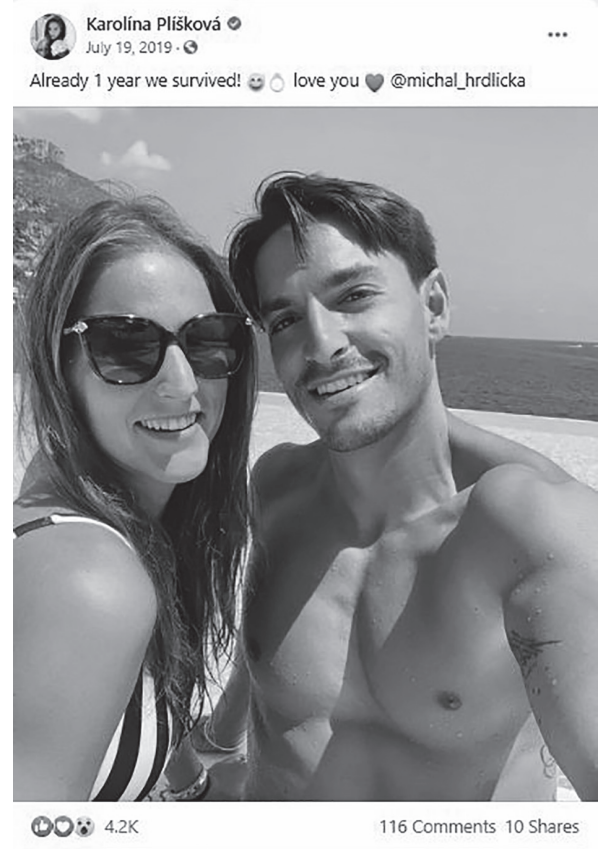

Figure 17 A photo of Karolína Plišková and Michal Hrdlička from the Facebook page of Karolína Plišková (July 18, 2019). 
Contrary to the previously mentioned athletes, the photos in which Karolína Plíšková posed or showed the glimpses of her non-sport life were occasionally accepted differently. The fans and visitors of Plíškovás page reacted negatively (seven posts elicited predominantly negative comments) to non-sports contributions released after unsuccessful matches or photos from her private life.

In the case of Karolína Plíšková, we can observe distinctions in the negative comments by Czech and English-speaking audiences as well. While reactions in English usually shamed Plíškovás poor sports performance, Czech speakers focused on her marriage; thus, the photos of Hrdlička and Plíšková were perceived negatively in the observation period. The concentration of Czech fans on Plíšková's relationship posts could be caused by the negative mediatization of her husband who has been commonly discussed in the Czech national tabloids (nh, 2020; om, tuš, 2017; venu, 2016). Figure 17 captures a characteristic photo of the couple that evoked critical reactions. For example, one fan stated that the Czech tennis player did not have a brain and there was no reason to congratulate Plíšková and her husband on their one-year wedding anniversary.

\section{DISCUSSION AND CONCLUSION}

The analysis of Czech female athletes' communication on their official Facebook pages and fans' reactions to them confirmed the results of previous studies conducted within other cultural backgrounds, usually U.S. or Western European, which is not surprising in the current globally connected world. Besides that, our research also brought new findings, especially in the field of fans' comments.

The athletes under study represented two generations with specific approaches towards social media; however, it was not always possible to distinguish the approach by the biological age of the athlete. More important than the age of the sportswomen was their professional age, which can be measured by the length of their international sports career. In general, the longer the athletes were in professional sports, the more conservative, professional and in some cases unpersonal their communication style was. The individual approaches also seemed to depend more on each athlete's personality and specific inclination towards social media. Using a slightly modified (instead of Instagram, we used Facebook) typology of Hagay and Bernstein (2019a), Martina Sáblíková belongs to the group of professional athletes who usually share only photos from their sports events, with a current trend to more "humanize" herself with more personal pictures. Petra Kvitová and Karolína Plíšková try to combine both professional and human approaches with Kvitová utilizing her page more for commercial endorsements and Plísková promoting her personal life, which unfortunately is not generally supported by her fans. Zuzana Hejnová started the analyzed period as a "human" athlete but with the increase in promotion of the various consumer contests of her partners has been slowly moving into a "pro Facebook" athlete, where Ester Ledecká and Eva Samková have already firmly established themselves.

Generally, the results of our study are in accordance with the previous findings of Toffoletti and Thorpe (2018). The selected athletes used their Facebook pages for the successful promotion of their achievements and had their own space for self-expression without the risk of being medially distorted in any way. All the athletes seemed 
to be well aware of this advantage and created portrayals of themselves as sexy and powerful (Bruce, 2016) professional athletes.

Content published during the athletes' on and off-season differed. While the seasonal posts were full of sports photographs and pictures of podium successes, the off-season content more often reflected the athletes' personal lives, such as glamour photos of themselves as beautiful women in nice gowns or swimsuits. Female athletes are sometimes stereotypically criticized for their lack of femininity (Cooky \& Dworkin, 2013). Therefore, they capitalize on any occasion during the off-season to show their audience a contrasting portrait. Still, this cannot be considered the rule, as it depends on the athlete's personality, e.g. Martina Sáblíková did not publish any photos of herself in a swimsuit and only rarely posted glamour photos within the analyzed time period and Eva Samková had a very similar approach.

Contrary to the findings of Browning and Sanderson (2012) or Fink (2015), fans predominantly treated the athletes with respect and sexually explicit or abusive remarks were not common. The overwhelming majority of fans' reactions was supportive and/or admiring. However, the results of the study proved that, throughout the same time period, the selected athletes faced various types of negative, hateful or inappropriate followers' comments and reactions that were caused not only by unsatisfactory sports results, but also by an overemphasis on sexuality, seemingly "non-feminine" appearance, body weight, or excess of promotional and commercial content (Mutz \& Meier, 2016 or Walsh et al., 2013). Although the negative, unfavorable, hateful or annoying comments occurred on the official Facebook pages of the selected female athletes, the reason for them in most cases was not (only) the sportswomen's sports performance but mainly the other aforementioned personal factors.

Some positive or negative comments were not related to the popularity of the sport and its spread in the Czech Republic. This fact was reflected, for example, in the high numbers of likes and shares of Martina Sáblíkovás posting, despite the fact that speed skating is not one of the most popular sports worldwide (Ozanne et al., 2017). The overtone of comments was also not directly related to the success or failure of selected athletes in the certain period, as the results this research shown.

Additionally, it was revealed that the Czech audience focused on different negative aspects of the athletes than English speaking fans. The international public generally focused on poor sports performance and results, while Czech fans criticized athletes' personal opinions or the consequences of their private life. For Czech fans, we can speculate it also depended on the media presentation of the athletes, for example, in the case of Petra Kvitová and her story with attack and injury, her positive outlook during interviews, etc. Karolína Plíšková, however, had a completely different media image largely associated with her husband's controversial reputation. Even though Kvitová and Plíšková represented the same sport, each was perceived differently by fans.

The case of Karolína Plíšková was unique and did not match the other athletes in our sample. Even though there was almost no difference in the proportion of Czech and English comments, the topics of the negative comments varied. The English were more hateful from assumed bettors and focused on Pliškovás game and failures while Czechs commented negatively on her personality, especially in connection to her husband. 
It would seem obvious that if the athletes are successful and win medals, only positive comments would follow under their posts, but this was not confirmed by our research. As mentioned above, on the Facebook page of Eva Samková, for example, in reference to a post about her podium success, one man commented that she was overweight, so she "did not win." Even success in the form of a medal was not enough in this case. Comments on the character and appearance of the athletes occurred in several instances. In addition to Eva Samková, this also was demonstrated on Karolina Plíškovás page. While Samková's fans defended her against these haters, the visitors of Plíškovás page did not react to the negative content.

Still, contrary to previous studies, negative comments represented only a tiny minority of all the fans' communication on the selected female athletes' Facebook pages, the majority being supportive reactions, expressing happiness for both the athletes' achievements and personalities. Therefore, we can conclude that in the case of the (self)presentation of professional Czech female athletes on social media there are advantages to doing so despite its risks. We witnessed that social media represents a high potential for female athletes to control their media images in an environment generally not hostile towards them.

Regarding the overall scope of the research, the authors concede that the results of this study are partially limited. At first, a relatively small sample of female athletes' pages was examined. Due to that, the results cannot be overgeneralized; each athlete communicated in her own way. The other factors that influenced the results were the disciplines in which selected athletes competed and the observation period. For the validation of results, it would be necessary to include more athletes from various sports disciplines in the sample. To sum up, the female athletes' social media communication and the fans' reactions are current topics and provide the implication for further research both in the Czech Republic and worldwide.

\section{DECLARATION OF CONFLICTING INTERESTS}

The author(s) declared no potential conflicts of interest with respect to the research, authorship, and/or publication of this article.

\section{ACKNOWLEDGEMENTS}

This work was supported by PROGRES Q19; Charles University Research Scheme; and Charles University Grant Agency under Grant GA UK no. 338119.

\section{REFERENCES}

Antonini, A., Gomez Mejia, G., \& Lupi, L. (2019). All We Do is "Stalking”: Studying New Forms of Reading in Social Networks. In: Proceedings of the 30th ACM Conference on Hypertext and Social Media, Hof, Germany.

BBC.com. (2020, August 13). Hannah Craig: Social Media Has Positives and Negatives for Female Athletes. BBC.com. Retrieved from https://www.bbc.com/sport/canoeing/53750191.

Billings, A. C., Butterworth, M. L., \& Turman, P. D. (2018). Communication and Sport: Surveying the field (3rd ed.). Thousand Oaks, CA: SAGE.

Bishop, J. (2014). Representations of 'Trolls' in Mass Media Communication: A Review of Media-texts and Mo.al Panics Relating to 'Internet Trolling'. International Journal of Web Based Communities, 10(1), 7-23. 
Browning, B., \& Sanderson, J. (2012). The Positives and Negatives of Twitter: Exploring How Student-Athletes Use Twitter and Respond to Critical Tweets. International Journal of Sport Communication, 5(4), 503-521.

Bruce, T. (2016). New Rules for New Times: Sportswomen and Media Representation in the Third Wave. Sex Roles, 74(7-8), 361-376.

Burch, L. M., Clavio, G., Eagleman, A. N., Major, L. H., Pedersen, P. M., Frederick, E. L., \& Blaszka, M. (2014). Battle of the Sexes: Gender Analysis of Professional Athlete Tweets. Global Sport Business Journal, 2(2), 43-61.

Cooky, C., \& Dworkin, S. L. (2013). Running Down What Comes Naturally: Gender Verification and South Africa's Caster Semenya. In: Wenner, L. A. (Ed.), Fallen Sports Heroes, Media, and Celebrity Culture (pp. 148-162). New York: Peter Lang.

ČTK. (2018, August 20). Zraněná Hejnová už letos nebude závodit. Př́ští rok se chce vrátit [Injured Hejnová will no longer race this year. She wants to come back next year]. Aktuálně.cz. Retrieved March 25, 2021, from https://sport.aktualne.cz/ostatnisporty/atletika /zranena-hejnova-uz-letos-nebude-zavodit-pristi-rok-se-chcev/r 2e1b1af6a44411 e89de10cc47ab5f122/.

Danesi, M. (2017). The Semiotics of Emoji: The Rise of Visual Language in the Age of the Internet. London: Bloomsbury Publishing.

Dawson, V. R. (2018). Fans, Friends, Advocates, Ambassadors, and Haters: Social Media Communities and the Communicative Constitution of Organizational Identity. Social Media + Society. Retrieved from https://doi.org/10.1177/2056305117746356.

Emmons, B., \& Mocarski, R. (2014). She Poses, He Performs: A Visual Content Analysis of Male and Female Professional Athlete Facebook Profile Photos. Visual Communication, 21(3), 125-137.

Evasamkova.cz (2014). Eva Samková: Snowboardcross. Evasamkova.cz. Retrieved from http://www.evasamkova.cz/english/.

Fink, J. S. (2015). Female Athletes, Women's Sport, and the Sport Media Commercial Complex: Have We Really “Come a Long Way, Baby”? Sport Management Review, 18(3), 331-342.

Franck, E., \& Nüesch, S. (2012). Talent and/or Popularity: What Does It Take to Be a Superstar? Economic Inquiry, 50(1), 201-216.

Fuchs, C. (2017). Social Media: A Critical Introduction (Second Edition). London: SAGE.

Hagay, H., \& Bernstein, A. (2019a). Israeli Sportwomen Self-presentation on Instagram [Conference talk]. IAMCR 2019. Madrid, Spain.

Hagay, H., \& Bernstein, A. (2019b). Israeli Sportwomen Self-presentation on Instagram [Abstract]. In: IAMCR 2019 Final Abstract Book: Media and Sport Section (pp. 70-71). Retrieved from https://iamcr.org/es/madrid2019/iamcr-2019-final-abstract-books.

Hardin, M. (2005). Stopped at the Gate: Women's Sports, 'Reader Interest'; and Decision Making by Editors. Journalism and Mass Communication Quarterly, 82(1), 62-77.

Hardin, M., \& LaVoi, N. M. (2013). The "Bully" and the "Girl Who Did What She Did": Neo-Homophobia in Coverage of Two Women's College Basketball Coaches. In: Wenner, L. A. (Ed.), Fallen Sports Heroes, Media, and Celebrity Culture (pp. 267-283). New York: Peter Lang.

Hejnova.cz (2020). Zuzana Hejnová: O mně [About me]. Hejnova.cz. Retrieved from https:// www.hejnova.cz/o-mne.

Jakubowska, H. (2015). Are Women Still the “Other Sex”: Gender and Sport in the Polish Mass Media. Sport in Society, 18(2), 168-185.

Jenkins, H. (2006). Convergence Culture: Where Old and New Media Collide. New York and London: New York University Press.

Karolina-pliskova.com (2020). Official Site of Czech Professional Tennis Player Karolína Plísková. Karolina-pliskova.com. Retrieved from https://www.karolina-pliskova.com/en. 
Kong, P., \& Harris, L. M. (2015). The Sporting Body: Body Image and Eating Disorder Symptomatology Among Female Athletes from Leanness Focused and Nonleanness Focused Sports. The Journal of Psychology, 149(2), 141-160.

Kubištová, D. (2020, December 7). Když ,fanouškům ‘ nevyjde tiket, píšou, že mě zabijí, říká Strýcová o obtěžování na sociálních sítích [When the 'fans' don't win the money from the bet, they write me that they will kill me, says Strýcová about harassment on social networks]. In: iRozhlas.cz [News]. Retrieved from https://www.irozhlas.cz/sport/barbora -strycova-rozhovor-obtezovani-socialni-site_2012071153_dok.

Kvitová, P. (2020, May 9). In: Facebook.com [Fan page]. Retrieved from https://www .facebook.com/petrakvitovaofficial/.

Lebel, K., \& Danylchuk, K. (2012). How Tweet It Is: A Gendered Analysis of Professional Tennis Players' Self-Presentation on Twitter. International Journal of Sport Communication, 5(4), 461-480.

Ledecká, E. (2020, April 8). In: Facebook.com [Fan page]. Retrieved from https://www .facebook.com/pg/esterledecka.cz/about/?ref=page_internal.

Lombard, M., Snyder-Duch, J. \& Bracken, C. C. (2002). Content Analysis in Mass Communication: Assessment and Reporting of Intercoder Reliability. Human Communication Research, 28(4), 587-604.

Lumsden, K., \& Morgan, H. M. (2012). 'Fraping', 'Sexting', 'Trolling' and 'Rinsing': Social Networking, Feminist Thought and the Construction of Young Women as Victims or Villains. In: Proceedings of Forthcoming Feminisms: Gender Activism, Politics and Theory (BSA Gender Study Group Conference), Leeds, UK.

Macek, T., \& Tomíček, J. (2018, August 11). Poraženi bolestí. Jak se mají Hejnová a další hvězdy vyhýbat zraněním? [Defeated by pain. How should Hejnová and other stars avoid injuries?]. iDnes.cz. Retrieved April 03, 2020, from https://www.idnes.cz/sport/atletika /me-berlin-ceska-atletikazraneni.A180810_235854_atletika_par.

Mondal, M., Silva, L. A., \& Benevenuto, F. (2017). A Measurement Study of Hate Speech in Social Media. In: Proceedings of the 28th ACM Conference on Hypertext and Social Media (HT '17), Prague, Czech Republic. Retrieved from https://doi. org/10.1145/3078714.3078723.

Mutz, M., \& Meier, H. E. (2016). Successful, Sexy, Popular: Athletic Performance and Physical Attractiveness as Determinants Of Public Interest in Male and Female Soccer Players. International Review for the Sociology of Sport, 51(5), 567-580.

nh (2020, May 25). Přiznání Hrdličky: Prachy na nule! Co na to Plíšková? [Hrdlička’s confession: Money at zero! What about Plíšková?]. In: Ahaonline.cz [News]. Retrieved from https://www.ahaonline.cz/clanek/ zhave-drby/172095/priznani-hrdlicky-prachy-na-nule -co-na-to-pliskova.html.

Nutrend.cz (2020). Martina Sáblíková. Nutrend.cz. Retrieved from https://www.nutrend.cz /martina-sablikova-a29722.htm.

om, tuš (2017, July 14). Sporták Hrdlička (28): Po Borhyové dostane prachy i z Plíškové! [Sports commentator Hrdlička (28): He will get money from Plíšková after Borhyová!]. In: Ahaonline.cz [News]. Retrieved from https://www.ahaonline.cz/clanek /zhave-drby/136090/sportak-hrdlicka-28-po-borhyove-dostane-prachy-i-z-pliskove .html.

Olympic.cz (2018a). Martina Sáblíková. Olympic.cz. Retrieved from_https://www.olympic.cz /sportovec/1499--martina-sablikova.

Olympic.cz (2018b). Petra Kvitová. Olympic.cz. Retrieved from_https://www.olympic.cz /sportovec/2754--petra-kvitova.

Ortiz, S. M. (2020). Trolling as a Collective Form of Harassment: An Inductive Study of How Online Users Understand Trolling. Social Media + Society. Retrieved from https:// doi.org/10.1177/2056305120928512. 
Ozanne, M., Cueva Navas, A., Mattila, A. S., \& Van Hoof, H. B. (2017). An Investigation Into Facebook "Liking" Behavior An Exploratory Study. Social Media + Society. Retrieved from https://doi.org/10.1177/2056305117706785.

Pegoraro, A. (2010). Look Who's Talking-Athletes on Twitter: A Case Study. International Journal of Sport Communication, 3(3), 501-514.

RedBull.com (2020). Eva Samková. RedBull.com. Retrieved from https://www.redbull.com /int-en/athlete/eva-samkova.

Riffe, D., Lacy, S., \& Fico, F. G. (2005). Analyzing Media Messages: Using Quantitative Content Analysis in Research (Second Edition). Mahwah, New Jersey: Lawrence Erlbaum Associates.

Sanderson, J. (2013). From Loving the Hero to Despising the Villain: Sports Fans, Facebook, and Social Identity Threats. Mass Communication and Society, 16(4), 497-509.

Sheffer, M. L., \& Schultz, B. (2015). The New World of Social Media and Broadcast Sports Reporting. In: Routledge Handbook of Sport Communication (pp. 210-218). New York: Routledge.

Smith, L. R., \& Sanderson, J. (2015). I'm Going to Instagram It! An Analysis of Athlete Self-Presentation on Instagram. Journal of Broadcasting \& Electronic Media, 59(2), $342-358$.

Statista.com (2020). Most Popular Social Networks Worldwide as of July 2020, Ranked by Number of Active Users. Statista.com. Retrieved from https://www.statista.com/statistics /272014/global-social-networks-ranked-by-number-of-users/.

Toffoletti, K., \& Thorpe, H. (2018). Female Athletes' Self-Representation on Social Media: A Feminist Analysis of Neoliberal Marketing Strategies in "Economies of Visibility." Feminism \& Psychology, 28(1), 11-31.

Trackalytics.com (2020). Free Social Media and Website Statistics/Analytics. Trackalytics. com. Retrieved from https://www.trackalytics.com/.

Vann, P. (2014). Changing the Game: The Role of Social Media in Overcoming Old Media's Attention Deficit Toward Women's Sport. Journal of Broadcasting \& Electronic Media, $58(3), 438-455$.

venu (2016, November 30). Dcera Borhyové pekla cukroví s přítelkyní Hrdličky: Dají mamince ochutnat? [Borhyová's daughter bake sweets with Hrdlička's girlfriend. Will the mum be able to taste it?]. In Blesk.cz [News]. Retrieved from https://www.blesk.cz /clanek/celebrity-ceske-celebrity/433441/dcera-borhyove-pekla-cukrovi-s-pritelkyni -hrdlicky-daji-mamince-ochutnat.html.

Voráček, J., \& Č́slavová, E. (2019). Effects of Sports Personalities in Marketing Communication on the Purchasing Preferences of Generation Y. AUC Kinanthropologica, 55(2), 107-127.

Walsh, P., Clavio, G., Lovell, M. D., \& Blaszka, M. (2013). Differences in Event Brand Personality Between Social Media Users and Non-Users. Sport Marketing Quarterly, 22(4), 214-223.

Wann, D. L., \& James, J. D. (2019). Sport Fans: The Psychology and Social Impact of Fandom. New York: Routledge.

Weiss, O. (1996). Media Sports as a Social Substitution Pseudosocial Relations with Sports Figures. International Review for the Sociology of Sport, 31(1), 109-117.

White, M. D., \& Marsh, E. (2016). Content Analysis: A Flexible Methodology. Library Trends, 55(1), 22-45.

Woodman, T., \& Hardy, L. (2003). The Relative Impact of Cognitive Anxiety and Self-Confidence upon Sport Performance: A Meta-Analysis. Journal of Sports Sciences, 21(6), 445-457.

Zlatkovský, M., \& Kočí, P. (2018, February 23). Od Rašky po Ledeckou: Cenné kovy letos pro Česko vybojovaly především ženy [From Raška to Ledecká: This year, the medals for Czechia were won mainly by women]. In: iRozhlas.cz [News]. Retrieved from https:// www.irozhlas.cz/sport/olympijske-hry/od-rasky-po-ledeckou-ceska-republika-uz-ma-ze -zimnich-olympiad-vic-medaili-nez_1802230635_zlo. 